\title{
"A IGREJA do DIABO" E O DISCURSO do CARNAVAL
}

\section{Zilia Mara Scarpari Schmidt e Edson Rosa da Silva}

\section{1 - NTRODUÇÃO}

Nosso estudo fundamenta-se nos concei:os bakhtineanos sobre a carnavalização. ${ }^{1}$

Para melhor entender este procedimento literário e como ele se atualiza no conto A lgreja do Diabo, de Machado de Assis, convém partirmos das definiçōes de monologismo, dialogismo e polifonia.

O universo de toda criação monológica se caraceriza por uma unidade de acento ideológico. Neste mundo homofônico, tudo está subordinado à última palavra de seu criador. Uma única consciência organiza e interpreta o mundo criado, um mundo compacto e de significação única, onde os seres são relficados. Por isso, na narrativa clássica, monológica, os personagens são planos, possuem contornos bem definidos e nunca transcendem seus traços típicos. Os dílogos refletem uma luta de vozes aparente, pois é o autor implícito que monopoliza o centro do discurso. A inter-relação de consciências não existe. Tudo se encerra num espaço fechado, subordinado a um campo de visão único.

Kristeva ${ }^{2}$ explica o processo monológico baseando-se na definição saussuriana de paragrama poético. $O$ paragrama poéiico de que fala Saussure em Anagrammes se estende de zero a dois. O zero denota, representa uma espécie de grau zero da escritura. O um é o "interdito" lingüístico, psíquico, social. E Deus, o totalitarismo, a hierarquia. Segundo Kristeva, é a lógica de um sis'ema baseado em 0-1 que caracteriza o discurso monológico. $O$ sujeito assume o papel

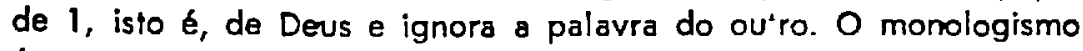
é portanto absolutista, teológico, dogmático, causal, científico, linear.

1 BAKHTINE, M. (1970 \& \& b)

2 KRISTEVA, J. (1969) p. 150 e seguintes. 
Se ele comporta uma oposição, esła fica a nivel diádico e maniqueísta.

A carnavalizaçāo bane todo discurso monológico de sua estrutura, que está baseada num esquema essencialmente dialógico.

dialogismo implica o aparecimento do 2, ou seja, a interação do eu (1) e do outro (2), abolindo portanto a lógica de um sistema na base de 0-1. O dialogismo está baseado numa, lógica relativista, de analogia e oposição não exclusiva. Segundo Bakhtine, as relaçōes dialógicas podem estabelecer-se tanto em enunciados completos como na palavia isolada, desde que nela duas vozes se afrontem dialogicamente.

E importante sublinhar que o dialogismo não se confunde com a dialética hegeliana. Esta pressupōe uma luta e uma projeção, o que, afinal, não transcende a lógica da causalidade, aristotélica. $O$ cialogismo absorve a dialérica, substituindo-a por um conceito de revelação. Não visa a nenhum avanço, mas a uma harmonia que implica uma idéia de ruptura como modo de transformação. No processo dialógico, as consciências, as vozes se afrontam, mas sem qualquer síntese. O que encontramos é, antes, uma coexistência de consciênciás anti.éticas, num mundo plural, onde tudo é estruturado de modo a deixar a oposição dialógica sem solução. Daí se conclui que o dialogısmo se manifesta plenamente numa criaçāo polifônica.

A polifonia se define então com a reuniaao de materiais absolutamente hete:ogêneos, como uma pluralidade de centros de consciência não reduzidos a um denominador comum ideológico. Na visão artística do universo polifônico não existe o devir, mas a coexistência e a interação. O mundo é visto e pensado não em termos de tempo, mas de espaço. Coexistência, justaposição, interação e simultaneidade, eis as palavras-chaves da polifonia.

O discurso em que dialogismo e polifonia se atualizam inteiramente é o discurso do carnaval.

Por carnavalização entende-se a influência do carnaval na literatura, e nos diferentes gêneros.

O "diálogo socrático" e a "sátira menipéia" são dois gêneros dos fins da Antiguiuidade clássica já marcados pela visão carnavalesca do mundo. Mas, é no Renascimento, sobrefudo nas obras de Boccace e Rabelais, que a carnavalização literá:ia se realiza em tada a sua plenitude. 
No ritmo carnava'esco anulam-se todas as distâncias entre o homem e o mundo e os homens entre si, estabelecendo-se um "contato livre e familiar", em oposição às relaçōes sócio-hierárquicas da vida diária. O universo carnavalesco é um mundo às avessas, marcado pela excentricidade, pela profanação ou rebaixamento dos valores consagrados, pela reunião dos contrários, pelas alianças desıguais.

As imagens carnavalescas, fundadas no oximoro, conjugam semas antitéticos: o sagrado e o profano, 0 alto e o baixo, o sublime e o grotesco, a tragédia e a comédia, a sabedoria e a estultícia, o éogio e a injúria, o nascimento e a morte, a face e o verso, a afirmação e a regação.

Entre os múltiplos atos carnavalescos (o "travestissement", as mistificaçōes, etc), o mais imporiante é o da "entronização - destronamento", o coroamento e a destituição do rei do carnaval. Este riival traduz todo o processo da queda e da subs.ituição, da morte e do renascimento, o caráter inevitável e ao mesmo tempo fecundo da mudança - renovação. Ambivalente desde o inicio, a entionização já contém a. idéia do destronamento futuro. Aliás, todos os símbolos carnavalescos se constróem nesta perspectiva ("dois em $u^{\prime \prime}$ ): ○ nascimento já pressupōe a morte, a morte já contém em si o mascimento. Dai a representação barroca da mo:te como uma ve'ha grávida em imagens de barro.

Este tipo de imagem faz nascer o riso carnavalesco, ambivalente e fecundo. E, intimamente ligada ao riso, está a paródia. Todo objeto tem sua paródia. Daí os pares carnavalescos de todo tipo, parodiando-se muivamente, formando um sistema de espelhos deformantes.

O tempo carnavalesco não é trágico, nem épico, nem histórico. Com suas próprias leis, ele engloba uma quantidade infinita de mudanças radicais e de metamorfoses.

O carnaval pressupōe também uma concepção não euclidiana do espaço. Alargando o palco estreito da vida privada, de uma época delimi.ada, a carnavalização introduz um palco universal, comum a todos os homens.

Apesar da perda de sua significação primitiva, de sua riqueza de formas e de símbolos, do caráter esselcialmente público que tinha até $0 X V I I$, o Carnaval continua a influenciar a litera:u:a, onde ele aparece atomizado. 
E assim enconiramos, na obra de Machado de Assis, o conto A Igreja do Diabo, bastante marcado pela carnavalizaçăo que aí se realiza com uma forma extremamente sutil de visão artística, como uma espécie de princípio heurístico que, relativizando tudo o que é estável, pré-estabelecido, oficial, permite penetrar nas questões mais complexas e compreender mais profundamente a alma humana.

\section{2 - A CARNAVALIZAÇAO EM "A IGREJA DO DIABO"}

A Igreja do Diabo manifesta o procedimento do que se convencionou chamar de carnavalização. No seu enirecruzamento de vozes, o discurso do carnava! remete aos mais diversos códigos: religioso, moral, político, social, mítico, liferário, etc. Mas, é sobretudo a partir da desarticulação do discurso religioso qué o conto se estrutura. A palavra sagrada é aqui retomada e iniroduzida no discurso profano, criando, pela pa:ódia, um espaço textual dialógico, divergente, polifônico.

O novo texto é marcado pela reunião dos contrários, pela 16. gica original das coisas às avessas, por rebaixamentos e profanaçōes que provocam o riso ambivalente.

O conto também apresenta traços da sátira menipéia e dos mistérios medievais, gêneros vizinhos profundamente carnavalescos.

Enfim, o processo da eterna mudança-renovaçāo que caracteriza a natureza carnavalesca se manifesta na própria estrutura cíclica do conto.

\section{1. - A parb́dia do discurso religioso}

Desde o título do conto, observa-se o processo da convergência dos opostos. O discurso da ordem não nos permitiria jamais a junção dos elementos igreja, que denota "templo cris:ão, autoridade religiosa, comunidade cristāos"3 e diabo, que significa "demônio, o chefe dos demônios, o gênio do mal"4, o transgressor da própria ordem. Aí está, logo de início, a figura do "espírito que nega", um personagem que encarna a estrutura do próprio discurso: trata-se de um discurso de transgressão que instaura. uma nova ordem, um novo cosmos.

Prevalecendo-se do c:édito que merecem os manuscritos religio.

3 FERREIRA, A. Buarque de Holanda

4 lbidem 
sos, o conto é atribuído, pelo seu narrador, a tradição beneditina, adquirindo, assim, o caráier mítico das histórias antigas ("conta um velho manuscrito beneditino"... $)$, e, paradoxalmenie, o status de uma estória religiosa.

O capítulo I apresenta a "idéia mirífica" do Diabo que se "sentia humilhado com o papel avulso que exercia desde sécu'os" (p. 9). Eis o mundo primitivo do Diabo, configu:ado como um reino cáóiico, naturalmente carnavalizado.

O espírito paródico do conto surge exatamente da intenção do Diabo, que quer imitar a organizaçāo eclesiástica. Ao conceber a fundação de sua. "hospedaria barata", o Diabo cria o duplo paródico da Igreja de Deus:

Escritu:a contra Escritura, beviário contra beviá:io, Terej a minha missa com vinho e pão à farta, as minhas prédicas, bulas, novenas e todo o demais aparelho eclesiástico. O meu credo será o núcleo universal dos espíríos, a minha igreja uma tenda de Abrazo. (p. 9).

Pela enumeração cômica de ritos religiosos, ele iniroduz o universo da paródia, cujas leis se fundamentam na imitação burlesca do já inscrito. Poderíamos até mesmo denominar essa oposição como sendo a rebeldia do código que se escreve (o do Diabo) contra o código já inscrito (o de Deus). Fica explíci'a a estrutura de oposição em que os lextos vão dialogar ("Escritura contra Escritura' e "bieviário contra beviário"). O processo de subversão da ordem que ai vai reinar ("Terei a, minha missa, com vinho e pão à farta") também não é menos claro. O discurso do Diabo toma igualmente o credo, símbolo da fé cristã e o transforma em "núcleo universal dos espiritos" que vão servi-lo. A alusão à "tenda de Abraão" rememora o pacto da antiga aliança entre Javé e o Patriarca ${ }^{6}$, cuja sacralidade é abolida no discurso da transgressão. Ao mesmo tempo em que o Diabo faz uma crítica a visão das religiōes, a intenção primeira da cainavalização acha-se aqui confirmada: a negação de qualquer ordem estabelecida e a criaçäo de um mundo novo, às avessas, através de um 'contato livre e familiar" que rebaixa o elemento sagrado e dá zo profano um caráter solene.

A aliança do Antigo Testamento, o conto opõe a revolta do Diabo que vai "ter com Deus para comunicar-the a idéia e desafia-'o" (p. 10). Surge, assim, a figura de um usurpador que reatualiza o

6 Gn 17

5 ASSIS, Machado de (1944) p. 9. A partir de zgora, as citaçōes do conto seräo imediatamente seguidos do número do página entre parènteses. 
mito de Prometev.

O capítulo II relata o diálogo entre Deus e o Diabo. Ora, se nos voltarmos para os texios bíblicos, encontraremos um dílogo em que se acham face a face esses dois personagens. Referimo-nos precisamente dे tentaçāo do deserto. ${ }^{7}$ Cotejando-se os dois textos, concluímos: a) que o espaço do diálogo não é o mesmo: no texto evangélico, Cristo está no deserto ("Enião, foi Jesus conduzido pelo espírito para o deserto, a fim de ser tentado pe'o Diabo". $)^{8}$, enquanto que, no texto do conto, o Diabo vai até o céu; b) e que o tema do diálogo também difere nos dois textos.

Entretanto, hó uma estrutura comum: duas consciências que se afron'am e se opōem. Nos dois casos, o Diabo procura colocar-se em posição superior a Deus, o que ressalta justamente a sua rebeldia. Senāo vejamos: a) no texto bíblico, lemos assim:

Levou-o ainda o diabo a um monte muito elevado, mostrou-lhe todos os reinos do mundo e seu esplendor, e the disse: "Todas estas coisas the darei, se, prostrado, me adorares". 9

b) no texto do conto, essa mesma altivez assim se revela:

O Diabo sorriu com certo ar de escámio e triunfo. Tinha alguma idéia cruel no espírito, algum reparo picante no alforje da memória, qualquer coisa que, nesse breve instante de eternidade, 0 fazía crer superior ao próprio Deus. (p. 12)

E bem verdade que o texto machadino, por ser o texto da paródia, introduz o elemento cômico, através do discurso irônico do Diabo. Tal discurso é uma espécie de máscaro que bem cabe nesse momento de carnavalizaçāo. O tratamento reverente que o demônio usa para com Deus contrasta com a irreverência e a ousadia de sua atitude. É que o aparato de sua linguagem fica, ao nivel do parecer, enquanto que sua rebeldia fica ao nivel do ser. Fingindo bondade e compaixāo pelo anciāo, sua linguagem deixa entrever a ironia:

Senhor, a explicação é fácil; mas permiti que vos diga: recolhei primeiro esse bom velho; dai-lhe o melhor lugar, mandai que as mais afinadas cítaras e alaúdes o re-

$7 M+4,1-11 ; M c 1,12-13$ e Le $\$ 13$

$8 \mathrm{Mt} 4-1$

9 Mt $4,8-9$ 
cebam com os mais divinos coros... (p. 11-12)

Mesmo quando confessa aos homens quem é, o Diabo o faz com propósitos enganosos, "para retificar a noçåo que os homens tinham dele e desmentir as histórias que a seu respeito contavam as velhas beatas" (p. 15). Ao nivel do ser, só estó a ratificar o seu caŕ́ter que se marca pelo ser da mentira, oculto sob o parecer-verdade.

Ao dizer que vai lançar a pedra fundamental de sua igrejo, a Diabo parodia mais uma vez a linguagem do Evangelho. Conhecemos a importáncia de Cefas, Pedro/Pedra, na formação da igreja cristã. E o próprio Cristo que assim nomeia Simão: "Quando Jesus o viu, disse: "Tu és Simão, filho de João. Chamar-te-ás Cefas, que quer dizer Pedra". ${ }^{10}$ Em outra passagem do Evangelho, ao confirmar a fé inquebrantável de Pedro, que o p:oclama como o "Cristo, - filho de Deus vivo", o mestre responde:

Bem-aventurado és, Simø̃o, filho de Jonas, pois não foram a carne e o sangue que te revelaram isso, mas meu Pai que está nos céusl Pois bem, eu te digo: Tu és Pedro e sobre esta pedra edificarei a minha lgreja $e$ as portas do Inferno não prevalecerão contra ela. ${ }^{11}$

Em uma de suas epistolas, o apóstodo São Paulo diz aos cristãos de Efeso:.

Estais contruidos sobre o fundamento, que são os apóstolos, e os profetas, sendo a pedra angular o próprio Cristo. ${ }^{19}$

Tươ isso dá ao gesio do Diabo o importância de um gesto criador. Vista à luz do texto segrado, essa padra fundamenial adquire uma signficação muito maior, ou seja, a. palavra de agora revigora-se na força da palavra primitiva. Sendo assim, a transgressão da ordem não é tão somente uma inversão do código religioso vigente, mas equivale à usurpação da. palavia mágica da divindade.

Há ainda que se notar a presença dos anjos, o que acentua ainda mais a semelhança entre os dois textos. $O$ texto bíblico termina assim: 'Deixou-o então o diabo, e eis que se aproximaram os anjos, que se puseram a servi-lo". O tex:o do conto de Machado, além

10 Jo 1,42

11 Mis $16,16-18$

12 Ef. 2,20 
de outras alusões aos serafins e aos coros angélicos, encerra o diálogo "entre Deus e o Diabo" como segue:

Debalde o Diabo tentou proferir albuma coisa mais. Deus impusera-Ihe o silêncio; os serafins, a um sinal divino, encheram o seu com as harmonias de seus cantos. 0 Diabo sentiu, de repente, que se achava no ar; dobrou as asas, e como um raio, caiu na terra. (p. 14)

Se, no texto do Evangelho, o Diabo desaparece logo em seguida, no texto do conto é ele que, no capítulo seguinte, vai desempenhar o papel mais importante. Com efeito, colocando-se no lugar de Cristo, é o Diabo quem anuncia a "boa nova aos homens". Temos que fazer, mais uma vez, algumas remissões às Escrituras. A expressão "boa nova" é a tradução literal do termo grego em que está calcada a palavra evangelho. O sentido desse termo já era, na língua clássica, o de "boa nova.". Encontramo-lo nos livros do Novo Testamento, sobretudo nas epístolas de São Paulo, com o sentido particular da "boa nova" da salvação anunciada pelo Cristo. Ora, é exatamente pelo fato de apodera:-se do dom de anunciar a verdade que o Diabo inverte as regras do jogo, proferindo, então, a sua verdade.

Sendo o disfarce próprio da carnavalização, não pode faltar ao demônio que, de volta à terra, enfia "a cogula beneditina". Assim vestido, sai a recruta- fiéis, parodiando, sem dúvida alguma, não só a doutrinação evangélica, como também, pela falácia de seu discurso, os comícios políticos: "Era assim que falava, a principio, para excitar o enfusiasmo, espertar as indiferentes, congregar, em suma, as multidões ao pé de si". (p. 15)

As pregaçōes do Diabo, a fim de implantar a sua igreja, evocam bem nitidamente o trabalho de evangelização do próprio Cristo. Confirmam-no ainda a presença das multidōes que o escutavarn. Compare-se o texto "As turbas corriam atrás dele entusiasmadaș" (p. 16) com esses dois exemplos dos muilos que poderiamos encontrar nos Evangelhos:

Descendo com eles, ele parou num lugar plano. Havia lá um grupo numeroso de discípulos e massa enorme de gente vinda de toda a Judéia e Jerusa'ém, de Tiro e Sidon, para ouvi-lo e serem curados das suas doenças. ${ }^{14}$

13 Bi 4,11

14 Le 6,17-18 
Um dia, a multidão se comprimia em sua volta a fim de ouvir a palavra de Deus e ele se achava de pé, às margens do lago de Genesaré. ${ }^{15}$

O que nos parece importante é que o Diabo, personagem do conto machadiano, tem consciência de que sua linguagem é fiuto deu ma astúcia reiórica ${ }^{16}$ que inverte as coisas em seu proveito. 0 exemplo seguinte ilustra esta consciência matalingǘstica:

Pela sua parte o Diabo promeia substituir a vinha do Senhor, expressão metafóiica, pela vinha do Diabo, locução direta e verdadeira, pois não faltaria nunca aos seus com o fruto das mais belas cepas do mundo. (p. 16)

E é desta redução do metafórico ao denotativo que nasce o riso:

On obtient un effet comique quand on affecte d'entendre une expression au propre, alors qu'elle é:aił employée au figuré. Ou encore: Dès que notre attention se concentre sur la matérialité d'une méraphore, l'idée exprimée devient comique. ${ }^{17}$

Os discursos desse politico habilidoso constituem um espaço intertextual em que, pelas alusōes e citaçōes que faz, confrontam-se textos variados, cuja distorção, em benefcio da verdade do prega. dor, é o principal elemento da comicidade:

Clamava ele que as virtudes aceitas deviam ser substituídas por ou:ras, que eram naturais e legítimas. A soberba, a luxúria, a preguiça foram reabilitadas, e assim também a avareza, que declarou não ser mais do que a mãe da economia, com a diferença que a mãe era robusta, e a filha uma esgalgada. A ira tinha a melhor defesa na existência de Homero; sem o furor de Aquiles, nāo haveria a llíada: "Musa, canta a cólera de Aquiles, filho de Peleu"... O mesmo disse da gula, que produziu as melhores páginas de Rabelais, e muitos bons versos do Hissope; virtude tão superior, que ninguém se lembra das batalhas de Luculo, mas de suas ceias; foi a gula que realmente o fez imortal. Mas, ainda pondo de lado essas razões de ordem literária ou histórica, para só mos-

15 Le 5,1

16 Por duas veze:, Deus chama o Diabo de "retórico", tf. p. 12 e 14.

17 BERGSON (1978) P. 87.88 
trar o valor intrínseco daquela virtude, quem negaria que era muito melhor sentir na boca e no ventre os bons manjares, em grande cópia, do que os maus bocados, ou a saliva de jejum? (p. 16)

A carnavalização atinge aqui toda a sua plenitude. Nesse ca. pítulo (III), assistimos, entre imagens glu:onas, a uma permutaçäo do alto e do baixo, ao destronamento das virtudes aceittas e $a$ entronização dos vícios e dos males proscritos pela moral oficial.

A referência explícita a Rabelais, às ceias de Luculo e ao Hissope $^{18}$, lembram a natureza carnavalesca da abundância, do exagêro, da hipérbole, da satisfação de todos os apetites.

Numa atmosfera de festa, a "cultura" é destronada para ceder lugar aos verdadeiros impulsos da "natureza". Deste modo, a sober. ba, a luxúria, a preguiça, a avareza, a ira, a gula, a inveja, a fraude, a calúnia são ent:onizadas. Por conseguinte, são rebaixadas "o perdão das injúrias e outras máximas de brandura e cordialidade", bem como "todas as formas de respeito". (p. 18)

Depois de pregar uma doutrina que inverte toda a ordem das coisas, "trocando a noçāo delas, fazendo amar as perversas e detestar as sãs" (p. 17), O Diabo ataca o segundo mandamento fundamental do Evangelho, o amor ao próximo, que lhe parece "um obstáculo grave à nova instifuição". Nos seus argumentos contra a noção do próximo, a referência a Galiani, padre napolitano conhecido pelo seu espirito bufäo e pelas cartas maliciosas que escrevia a Me. d'Epinay ${ }^{19}$, é mais uma nota carnavalizante neste contexto paródico.

Enfim, todo um universo d̀s avessas é criado, graças ao discurso transgressor do Diabo. Se as inversōes já provocam o riso, a retórica falaciosa do Diabo acentua a comicidade do seu discurso.

E sabido que o elemento cômico, em Machado, é parcimonioso, porque proveniente do "humorista", que Bergson define como

18 Luculo (109.57 AC), um dos melhores generais romanos e dos mais brilhantes oradores de seu tempo, celebrizou-se pelo seu luxo e, sobretuda pela mesa requintada - forta Cf AUGE (1928) v. 4 p. 544

- Hissopo, poema herói-cómico de Antonio Diniz da Cruz e Silva, é uma sátira social so feudalismo declinante e so alto clero contaminado pela ignor sualidade.

cf. COELHO, Jacinto do Prado. (1973) v. 1. p. 390-391

19 ef AUGÉ (1928) 
"un moraliste qui se déguise en savant, quelque chose comme un anatomiste qui ne ferait de la dissection que pour nous dégoúter"20. Descendo ao fundo do mal, o humorista acentua-lhe as particularidades $\infty \mathrm{m}$ a mais fria indiferença científica, descreverido "minutreusement ef méticuleusement ce qui est, en affectant de croire que c'est bien là que les choses devraient être"21. A Igreja do Diabo, porém, rompe momentaneamente esta norma. Entre o riso reduzido do Diabo que a princípio "sorri com certo a: de escárneo" ou que "recolhe o riso" (p. 12) e o seu pasmo final diante da verdade relativizada (p. 22), insere-se a euforia carnavalesca do capítulo III que a paródia do discurso religioso faz explodir.

\section{2. - Nos traços da sátira menipéia}

A sátira menipéia, gênero cuịas origens remontam à antigüidade clássica, tem seu nome ligado a Mênipo de Gadaro, filósofo grego do século III, a Varrão, śbbio romano do século I A.C., • Sêneca, a Luciano, apuleio e a Pet:ónio. A menipéia exerceu enorme influência na literatura cristõ, desenvolveu-se com variantes $e$ diferentes nomes na ldade Média, prolongou-se até o Renascimento a sua essêncio repercute ainda na literatura carnavalizada de hoje.

Relativizando os valores aceitos, as normas de conduta, jugando com as reviravoltas, com a elevação e a queda, com a surpresa da aproximação inesperada de objetos distantes e disparates, com os contrastes violentos, os ecândalos e as extravagância, a menipéia se integra na peispectiva da carnavalização.

As aventuras, as peripécias, o maravilhoso, a imaginaçăo, a alegoria, o naturalismo e o diálogo filosófico fundem-se na meditação sobre a verdade, sempre relativizada e objeto de eterna busca.

O universo filosófico da menipéia obedece a uma estrutura em três planos: a terra, o céu e os infernos, espaços que, nas suas aventuros, a Idéia percorre. Por tratar das questōes últimas numa atmosfera carnavalizada, a menipéia atribui papel importante à representação dos infernos, o que favorece o procedimento do "diálogo dos mortos", amplamente explorado na literatura européia dos séculos XVII e XVIII, e também o "dialogue sur le sevil", uma conversação filosófica no limiar do céu ou à entrada dos infernos.

20 BEGSON (1978) p. 98

21 ibidem P. 97 
Enfim, carnavalizando a verdade, a menipéia quebra a unidade épica e trágica do mundo em favor de uma atitude dialógica, ontiavioritária.

Ora, o conto de Machado apresenta todas estas caracteristicas.

A narrativa da sátira menipéia inicia-se geralmente mostrando um personagem que se julga o único detenior da verdade, mas que será paulatinamente contestado pelos outros personagens. Este procedimento dialógico se repete no conto machadiano. Ju'gando se "o nosso verdadeiro pai", o Diako c:ê-se o dono de uma sabedoria incontestável e capaz de fazer calar o próprio Deus. Entretanto, à medida que a narrativa avança, o espírito da negação será por sua vez negado pelos seus próprios fiéis e, dentre eles, por aquele perfeito ladrão árabe "que tepava a cara para ir às mesquitas", ou pelo calabrês fálsificador que, "tendo angariado a amizade de um cônego - vi ai uma dose da ironia machadiana - ia todas as semanas confessar-se com ele numa cape'a solitária" (p. 21), sem esquecer o droguista do Levante que, restabelecendo a ambivalência orıgınal da palavra grega pharmacon, envenena uma geração inteira, mas acaba socorrendo os filhos das vitimas com o produto das drogas. Eis o processo dialógico da negação do espírito que nega ou uma nova versão do aprendiz de feiticeiro. Se a inversão do mundo provoca o riso carnavalesco, a inversão do mundo invertido não é menos cômica.

A sincrese, um dos elementos constifutivos do "diálogo soctatico", definida como a confrontação de vários pontos-de-vista sobre um tema dado, é também uma das caracte:ísticas da menipéia. Se neste gênero encontramos sincreses dialógicas violentas entre o tentador e o tentado, o crente e o descrente, o justo e o pecador, o pobre e o rico, o conto em estudo nos oferece a sinciese evangé'ica entre Deus e o Diabo.

Para ilustrar a questão última da relatividade do bem e do mal, nada melhor que um universo às avessas como palco das extravagâncias do Diabo e das peripécias mais inespe:adas da Idéia. Num espaço carnavalizado, Salā reorganiza o mundo e, para ianto, empreende fantásticas viagens entre o inferno, o céu e a terra. Com a mesma facilidade com que "arranca da sombra para o infinito azul" (p. 10), desce à terra "como um raio" (p. 14). Enfusiasmado com as obras de expansāo de sua igreja, movimenta-se livremente entre a terra e os abismos: "E descia, e subia, e examinava tudo, retificava tudo" (p. 18). Finalmente, decepcionado, "voa de novo aos céus" 
(p. 22). Eis os três planos da menipéra onde a imaginação tem livre curso e onde a verdade se relativiza.

Como se vê, o espaço carnavalizado não obedece a uma concepção euclidiana. O conto mostra, um espaço cósmico, como o da menipéia, apropriado para o universalismo filosófico do tema. E, num cenário cósmico, também o tempo extrapola todos os limites.

No nivel diegético do conto e na perspectiva de um tempo cósmico carnavalizado, a eteinidade não passa de um breve instante, - Diabo conclui uma observação "começada desde alguns séculos" (p. 12), sua voz reboa "nas entranhas do século" (p. 14), eic.

Além do alto e do baixo, o conto alude também ao liminar "meripeano". Uma conversação filosófica no limiar do céu, onde se afrontam dialogicamente Deus e o Diabo a respeito de um outro recém-chegado, lembra o "dialogue sur le sevil" tão explorado pela sátira menipéia:

Deus recolhia um anciāo, quando o Diabo chegou so céu. Os serafins que engrinaldavam o recém-chegado, detiveram-se logo e o Diabo deixou-se es.ar à entrada com os olhos no Senhor.

- Que me queres fu? pe:guntou este.

- Não venho pelo vosso servo Fausto, respondeu o Diabo, rindo, mas por todos os Faustos dos séculos e dos séculos.

- Explica-te.

- Senhor, a explicação é fácil; mas permiti que vos diga: reco'hei primeiro este bom velho; dai-lhe o melhor lugar, mandai que as mais afinadas cítaras e alaúdes o :ecebam com os mais divinos coros...

- Sabes o que ele fez? Perguniou o Senhor, com os olhos cheios de doçuro.

- Não, mas provavelmente é dos últimos que virão ter convosco... (p. 11-12)

- ...e sabes tu o que ele fez?

- Já vos disse que não. 
- Depois de uma vida honesta, teve uma morte sublime. Colhido em um naufrágio, ia salvar-se numa tábua; mas viu um casal de noivos, na flor da vida, que se debatiam já com a morte; deu-lhe a tábua de salvaçāo $e$ mergulhou na éernidade. Nenhum público: a água e o céu por cima. Onde achas aí a frania de algodão?

- Senhor, eu sou, como sabeis, o espírito que nega.

- Negas esta morte?

- Nego tudo. A misantropia pode tomar aspecto de caridade; deixar a vida aos outros, para um misantropo, é realmente aborrecê-los...

Segundo Bakhtine,

le haut, le bas, l'escalier, le seuil, l'entrée, le palier ont une signification de point où s'effectuent la crise, le chan. gement radical, la cassure inattendue du destin, où des décisions sont prises, les barrières de l'interdit franchies, où l'on se renouvelle ou bien se perd. ${ }^{22}$

Como na menipéia, a ação de A lgreja do Diabo se passa não somente aqui e agora, mas no universo inteiro e na eternidade. $O$ céu. a terra, o inferno e o limiar transformam-se em espaços ambivalentes nos quais o tempo c:onológico é abolido. Só importa o tempo da crise, da confrontação dialógica, das mudanças radicais e das metamorfoses.

\section{3 - Nos tracos dos mistérios medievais}

O dialogismo aumenta no conto a importância do diálogo (direto ou indireto), fazendo crescer, com isso, o elemento dramático.

Certos aspectos do conto são marcados peía teatralidade, lembrando nāo só a sátira menipéia, que concebe o mundo como um grande teairo em cujo palco se dão os encontros decisivos do homem consigo mesmo, tendo por cenário o infinito, mas também os mistérios, variantes teatrais da menipéia na Idade Média.

Os três planos da menipéia que representam o céu, a terra e os infernos tiveram grande repercussão na estrutura dos mistérios e na sua topografia cênica; ambos os gêneros se preocupam com os destinos do homem e compoitam elementos cômicos e cenas vulgares que os integram na perspectiva da cainavalização. Daí o parentesco interno entre os dois gêneros, ligados igualmente pela sua proximi-

22 BAKHTINE (1970 •) p. 226 
A importância crescente do elemento cômico, de cenas grosseiras e de obscenidades, em detrimento do caráter hierático, provocou, em 1548, a proibição dos mistérios, em nome da religião e da decência. A solução encontrada pelos autores pareceu p!ausivel às auto:idades: ampliou-se o papel do drabo, sobre o qual recaiu eniāo toda a responsabilidade das afrontas à moral vigente.

A estrutura espacial e a importância conferida ao pape! do anjo transgressor, que aparece agora como um personagem bufo, são traços característicos que o conto foi indiretamente buscar nos mistérios medievais.

A bufonaria satânica se manifesta, no conto, nos gestos teat:ais do Diabo, expressos hiperbolicamente pelo texto:

Dizendo isto, o Diabo sacudiu a cabeça e estendeu os braços, com um gesio magnífico e varonil. Em seguida, lembrou-se de ir ter com Deus para comunicar-lhe a idéia $\mathbf{e}$ desafiá-lo; levantou os olhos, acesos de ódio, ásperos de vingança, e disse consigo: - Vamos, é tempo. E rápido, batendo as asas, com tal estrondo que abalou todas as províncias do abismo, arrancou da sombra para o inf:nito azul. (p. 10).

Mais adiante, lemos: "O diabo sentiu, de repente, que se achava no ar; dobrou as asas e, como um raio, caiu na terra. No capítulo III, entra a espa!har sua, doutrina "a grandes golpes de eloqüência", "com uma voz que reboava nas entranhas do século" (p. 14). A exageração é, pois, sistemática, daí sua comicidade. ${ }^{23}$

O texto cômico, polifônico, nasce, pois, de dois discuisos divergentes: o do Diabo e o do narrador, que rela.iviza com as tintas do exagero e da ironia o comportamento e o modo de ser e de pensar do personagem bufo.

\section{4 - O esquema cíclico do conto}

O processo dialógico de rela'ivização da verdade é a mola p:opulsoia da engrenagem cíclica do conto A Igreja do Diabo. Nesta estrutura, a anacrese, outro elemento do diálogo socrático, desempenha um papel importante.

A anacrese é a provocação da pa'avra pela palavra e compreen23 of BERGSON (1978) p. 95 
de os mais variados meios de fazer nascer o discurso do interlocuior. O conto pode ser definido como "a anacrese de um discurso anacrético" ou como uma grande anacrese de base cíclica: a palavra oficial de Deus provoca a palavra transgressora do Diabo, que provoca a palavra restauradora de uma nova o: dem, etc. Deste modo, o conto abre a possibilidade de uma continuação, um novo conto poderia escrever-se sobre a estrutura do primeiro.

Este caráter cíclico, repefitivo, é uma constante em todo contexto tipicamente carnavalizado.

Contra toda posiçāo monológica, a percepção carnava!esca do mundo nada tem a ver com o processo negativista do eterno retorno do mesmo, porque ela int:oduz sempre o avanço das metamorfoses continuas, das mudanças-renovações. Nesta perspectiva, o conto mostra o progresso do discurso autoritário de Deus que se relativiza na confroniação dialógica com o discurso de Satã.

O ríual do co:oamento e da destifuição do rei do Carnaval simboliza todo processo cíciclo de queda e substituiçāo, de morte e renascimento, de mudança e renovação. Invertendo todos os valores consagrados pela moral religiosa, o Diabo destitui a pa'avra divina e entroniza a sua frópria verdade. Se a estória terminasse ai, tal verdade seria tomada como absoluta e o ato de rebeldia da carnava-

lização em nada haveria de diferir de qualquer outro discurso autoritário. Mas, o ritual carnavalesco não separa entronização e destronamen'o. Ambivalente desde o início, o coroamento já contém em si a idéia da destifuição futura. Com "brados de triunfo", Satã fesieja sua própria entronização. $O$ auge da euforia anuncia entretanto o declinio do poder: "Um dia, porém, longos anos depois, notou o Diabo que muitos dos seus fiéis, às escondidas, praticavam as antigas virtudes." (p. 20)

A partir daí começa a transgressão da ordem transgredida, o mundo às avessas sofre uma nova inversão e, assim, as duas ordens se nivelam e todos os valores acabam equivalendo-e: 'se os mantos de veludo rematam em fianjas de algodão, as capas de algodão têm franjas de seda." Eis a relatividade da verdade que nada mais é do que a eterna contradição humana.

\section{3 - CONCLUSAO}

O esiudo da linguagem narrativa do conto A Igreja do Diabo, de Machado de Assis, revela uma estrutura dialógica e carnavalizada. 
A ideologia não é veiculada por um único ponto-de-vista, autoritário e absoluto, mas por um complexo polifônico onde se desiacam dois discursos que se afrontam dialogicamente: o de Deus e o do Diabo. A verdade, relativa, nasce en:ão desta luta de vozes e se define tão somente enquanto busca, enquanto eterno questionamento.

No texto machadiano, tudo se relativiza. Assim como a palavra divina é relativizada pela palavra de Sałã, a palavra de Deus relativiza - discurso transgressor do Diabo. A relaiivização não se dá somente no plano diegético, mas também ao nível da palavra do narrador. Relegando a um velho manuscrito beneditino a responsabilidade do seu discurso, o narrador abstém-se de qualquer intervenção direła. Este distanciamento crítico relativiza o todo narrado, impedindo que ai se adivinhe qualquer posição monológica.

Manifestando vestígios da sátira menipéia e dos mistérios medievais, o conto se escreve na perspectiva da carnavalização, onde a contestação da linguagem autoritária, a coincidentia oppositorum, as extravagáncias, os processos de inversão e as reviravolias provocam o riso ambivalente, ligado intimamente à pa:ódia do discurso religioso, a partir do qual o conto é estruturado.

A carnavalização, profundamente dia!ógica, se estende até a configuração cíclica do con'o, abrindo novas perspectivas de recriação, na medida, em que todo dialogismo se instaura como esc:itura - leituro.

Assim, A Igreja do Diabo é uma obra aberta. A:ravés de sua estrutura carnava:izada, ilustra de modo exemplar a incapacidade do espirito humano de chegar a uma verdade absoluta, porque, como diz Bakh:ine,

il ne s'est passe dans le monde rien de définitif, le derniar mot du monde et sur le monde n'est pas encore dit; celuicireste ouvert ef lib:e, tout est encore devant nous et se:a toujours devant nous. ${ }^{24}$

24 BAKHTINE (1970 d) p. 221 


\section{4 - BIBLIOGRAFIA}

4.1 - ASSIS, Machado de. A Igreja do Diabo. In: - - - Obra Complese - Rio do Janeiro, Jackson, 1944, 9. 9-22.

4.2 - AUGÉ, P. Larousso du XXC siècle. Paris, Larousse, 1928. v. 3.

4.3 - BAKHTINE, M. L'oouvre de François Rabelais et la culture populaire au Moyon Age of sous la Renaisiance. Paris, Gallimard, 1970 (b). 471 p.

4.4 - __. La poórique do Dostoióvgki. Paris, Sevil, 1970 (a) 352 p.

4.5 - - - - Esthéfique ef théorie du roman. Paris, Sevil, 1978. $450 \mathrm{p}$.

4.6 - BARTHES, R. S/Z. Paris, Sevil, 1970. 289 p.

4.7 - BERGSON, H. Le rire. Paris, Puf, 1978. 157 p.

4.8 - Biblla SAGRADA. Rio de Janciro, Sociedade Biblica do Brasil, 1968. 309 p.

4.9 -CALVET, Mgr. Polyoucte de Comoille. Paris, Ed. de la Pensée Moderne, 1968. $320 \mathrm{p}$.

4.10 - COELHO, Jacinio do Prado. Dicionário de literatura Porto, Figueirinhas, 1973. 3v.

4.11 - FERREIRA, A. Buarque de Holanda. Novo Dicionário da língua portuguesa. Rio de Jansiro, Nova Fronteira (s.d.)

4.12 - GenetTE, G. Figures III. Paris, Seuil, 1970. 285 p.

4.13 - JENNY, Loureni. Le discours du Carnaval. Littórature. Paris, Larousse. 16:19-36, out/dez. 1974.

4.14 - KRISTEVA, J. Semiotique, recherches pour une sómanalyse. Paris, Seuil, 1969. $380 \mathrm{P}$.

4.15 - ZUMTHOR, Pául. Essai de poétique módievalo. Paris, Seuil, 1972. 518 p.

\section{RESUMO}

A Igreja do Diabo, eento de Machado de Assis, aqui obordado sob a perspectiva da carnavalização enquanto procedimento literário. Fundamentado na parb́dia do discurso religicso, o texio de Machado apresenta igualmente traços da sátira menipéia dos mistéitos medieva's, gêneros vizinhos amplamente carnavalizados. O carnaval, profundamente dialógico, sc estende até a configura̧̧ăo cíclica do conto, abrindo novas possibildades de ro-crizşăo, na medida em que lodo dialogismo se instaura como escrituraticitura.

\section{RESUME}

A Igrija do Disbo, conto de Machado de Assis, est étudié ici sous la perspective de la carnavalisation en tant que procédé littéraire. Fondé sur la parodie du discours reiigieux, le texte de Machado présente également des traits de la satyre ménippée et des mystéres du Moyen Age, deux genres marqués par le discoups du carnaval. La carnavalisation, profondément dialogique, se manifeste aussi dans la structure cyclique du conte, suscitant d'autres possibilités de ré-créstion, dans la mesure oú tout dislogisme se définit comme écriture-lecture. 